\title{
PENERAPAN METODE SAS UNTUK MENINGKATKAN KEMAMPUAN MEMBACA PERMULAAN SISWA KELAS I SEKOLAH DASAR
}

\author{
Maimana $^{1}$, M. Syahrul Rizal ${ }^{2}$, Nurhaswinda ${ }^{3 *}$ \\ ${ }^{1}$ (PGSD, Universitas Pahlawan Tuanku Tambusai, Riau). \\ ${ }^{2,3}$ (Dosen PGSD, Universitas Pahlawan Tuanku Tambusai, Riau). \\ * Corresponding Author. E-mail: ${ }^{1}$ maimanayaru6@gmail.com
}

\begin{tabular}{|l|l|l|}
\hline Receive: 13/05/2021 & Accepted: 23/08/2021 & Published: 01/10/2021
\end{tabular}

\begin{abstract}
Abstrak
Penelitian ini dilatar belakangi oleh rendahnya kemampuan membaca siswa di kelas I SDN 009 Pulau Jambu Kecamatan Kuok Kabupaten Kampar. Salah satu solusi untuk mengatasi masalah ini adalah dengan menggunakan metode structural analitik sintetik (SAS). Tujuan penelitian ini untuk mendeskripsikan peningkatan kemampuan membaca permulaan siswa dengan menggunakan metode structural analitik sintetik (SAS) pada siswa kelas I SDN 009 Pulau Jambu. Metode penelitian ini adalah Penelitian Tindakan Kelas (PTK) yang dilaksanakan dalam dua siklus. Setiap siklus terdiri dari dua pertemuan dan empat tahap, yaitu perencanaan, pelaksanaan, observasi, refleksi. Subjek penelitian ini siswa kelas I SDN 009 Pulau jambu yang berjumlah 20 siswa. Teknik pengumpulan berupa observasi, tes, dan dokumentasi. Hasil penelitian ini dapat disimpulkan bahwa kemampuan membaca permulaan kelas I SDN 009 Pulau Jambu pada siklus I siswa yang tuntas 12 siswa atau $60 \%$, dan pada siklus II siswa yang tuntas secara keseluruhan adalah 17 siswa atau $85 \%$. Dengan demikian dapat disimpulkan bahwa dengan menggunakan metode structural analitik sintetik (SAS) dapat meningkatkan kemampuan membaca permulaan kelas I SDN 009 Pulau Jambu.
\end{abstract}

Kata Kunci : Membaca Permulaan, Metode Struktural Analitik Sintetik (SAS)

\section{Application of Synthetic SAS to Improve Beginning Reading Ability of Elementary School Students}

\begin{abstract}
This research is motivated by the low reading ability of students in class I SDN 009 Pulau Jambu, Kuok District, Kampar Regency. One solution to solve this problem is to use the synthetic structural analysis (SAS) method. The purpose of this study was to describe the improvement of students' initial reading skills using the synthetic structural analytical method (SAS) in first grade students of SDN 009 Pulau Jambu. This research method is Classroom Action Research (CAR) which is carried out in two cycles. Each cycle consists of two meetings and four stages, namely planning, implementation, observation, reflection. The subjects of this study were the first grade students of SDN 009 Pulau Jambu, totaling 20 students. The collection technique is in the form of observation, test, and documentation. The results of this study can be concluded that the ability to read at the beginning of class I SDN 009 Pulau Jambu in the first cycle of students who completed 12 students or $60 \%$, and in the second cycle students who completed the whole were 17 students or $85 \%$. Thus, it can be concluded that using the synthetic structural analytical method (SAS) can improve reading ability at the beginning of class I at SDN 009 Pulau Jambu.
\end{abstract}


Jurnal Edumaspul, 5 (2), Year 2021 - 167

(Maimana, M. Syahrul Rizal, Nurhaswinda)

Keywords : Beginning Reading, Synthetic Structural Analytical Method (SAS)

\section{Pendahuluan}

Undang-undang No. 20 Tahun 2013 pasal 3 tentang Sistem Pendidikan Nasional merumuskan tujuan Pendidikan Nasional yang berfungsi "mengembangkan kemampuan dan membentuk watak serta peradaban bangsa yang bermartabat dalam rangka mencerdaskan kehidupan bangsa, bertujuan untuk berkembangnya potensi peserta didik agar menjadi manusia yang beriman dan bertakwa kepada Tuhan Yang Maha Esa, berakhlak mulia, sehat, berilmu, cakap, kreatif, mandiri, dan menjadi warga negara yang demokratis serta bertanggung jawab". Untuk mencapai tujuan itu, sekolah dasar sebagai sebuah lembaga formal dalam memberikan layanan pendidikan berperan mendorong tumbuh kembang anak, termasuk meningkatkan keterampilan berbahasa, khususnya dalam membaca dan menulis permulaan.

Mata pelajaran Bahasa Indonesia mempunyai fungsi yang strategis, yakni sebagai sarana pembinaan kesatuan dan persatuan bangsa, sarana peningkatan pengetahuan dan keterampilan dalam rangka pelestarian dan pengembangan budaya, sarana peningkatan pengetahuan dan keterampilan untuk meraih dan mengembangkan ilmu pengetahuan, teknologi, dan seni, saran penyebarluasan pemakaian bahasa Indonesia yang baik untuk berbagai keperluan menyangkut berbagai masalah, sarana pengembangan penalaran, dan sarana pemahaman beragam budaya Indonesia melalui khazanah kesusastraan Indonesia (Kurikulum 2013, Depertemen 2013).

Untuk mencapai target tujuan di atas, Depdiknas merumuskan Kompetensi Dasar mata pelajaran Bahasa Indonesia SD dan MI, adalah sebagai berikut ; 1) mendengarkan; 2) berbicara; 3 ) membaca; dan 4) menulis. Dalam upaya penerapan Kurikulum 2013, pemikiran tentang pentingnya keberadaan pengembangan suatu model pembelajaran pada pengajaran bahasa Indonesia, dipandang sebagai tuntutan kebutuhan yang sangat mendasar. Berkaitan dengan itu, Sekolah Dasar atau MI dapat menghasilkan lulusan yang memiliki dasar-dasar karakter, kecakapan, keterampilan, dan pengetahuan yang memadai untuk mengembangkan potensi dirinya secara optimal. Variabel yang dapat menentukan keberhasilan pembelajaran bahasa Indonesia ditentukan oleh pengajar, pembelajar, bahan ajar, proses pembelajaran, dan penilaian.

Berdasarkan rumusan di atas, kegiatan pembelajaran bahasa Indonesia hendaknya mampu mengembangkan dan mengarahkan siswa dengan segala potensi yang dimilikinya secara optimal, yaitu guru dapat mendorong siswa untuk berpikir secara kritis. Keberhasilan pelaksanaan proses pembelajaran di kelas, terkait dengan kemampuan guru, baik sebagai perancang pembelajaran maupun pelaksanaan di lapangan. Guru dituntut mampu melakukan pembaharuan khususnya dalam pembelajaran bahasa Indonesia, yaitu dengan merancang pembelajaran berdasarkan pengalaman belajar bagi siswa sehingga menghasilkan pembelajaran yang bermakna.

Pembelajaran bermakna apabila mengarah pada pendekatan pembelajaran yang menunjang penciptaan belajar siswa secara aktif dan kreatif, akan dapat memotivasi siswa dalam kegiatan belajarnya. Kebermaknaan proses dan hasil pembelajaran ditentukan pula oleh kinerja guru dalam unjuk kemampuan profesionalismenya di lapangan, mulai menyusun rancangan pembelajaran hingga pada tingkat operasionalnya dapat menggunakan keragaman metode, media, sumber pembelajaran, serta penilaian yang dikembangkan.

Kecenderungan yang terjadi di lapangan, setelah dilakukan pengamatan 
terhadap proses pembelajaran yang berlangsung di kelas 1, guru masih "gramatika centris". Guru banyak mengajarkan gramatika (struktur bahasa) untuk diketahui dan dihafalkan siswa. Padahal struktur bahasa diajarkan untuk dipahami, dengan cara siswa dilatih menyusun kata membentuk kalimat. Guru yang menggunakan metode pembelajaran secara konvensional tidak akan memberikan kesempatan kepada siswa untuk berekspresi, berkreasi, eksplorasi, dan berinovasi, sehingga tidak merangsang siswa untuk membangkitkan minat, dan gairah untuk belajar. Penggunaan bacaan teks oleh guru, menyebabkan kadar daya menyimak siswa rendah. Dalam pengelolaan kelas, guru lebih mendominasi pembelajaran daripada siswa, sehingga tidak terwujud pola interaksi antara gurusiswa serta siswa dengan siswa lainnya.

Berdasarkan observasi peniliti pada tanggal 03 Maret dan 05 Maret 2021, permasalahan yang terjadi adalah menunjukkan bahwa kemampuan membaca permulaan siswa masih rendah, khususnya siswa kelas I SDN 009 Pulau Jambu yang kemampuan membaca permulaannya masih sangat rendah, hal ini dibuktikan oleh hasil belajar siswa dalam kemampuan membaca permulaan masih dibawah kriteria ketuntasan minimum (KKM) yang telah ditetapkan sekolah dasar sebesar 70. Dari 15 siswa, hanya 3 siswa yang mampu membaca dengan baik (20\%), sedangkan 12 siswa masih belum mampu membaca dengan baik (80\%). 12 siswa yang belum mampu membaca dengan baik itu terbagi dalam beberapa kategori diantaranya, belum mengenal huruf dan tidak lancar mengucapkan huruf, tidak bisa mengeja huruf menjadi suku kata, tidak bisa mengeja suku kata menjadi kata, dan masih banyak yang belum lancar dalam membaca sebuah kalimat. Faktor penyebab masih rendahnya hasil kemampuan membaca siswa disebabkan karena kemampuan membaca siswa masih sangat kurang, seperti kefasihan dalam membaca kurang lancar, selain itu pelafalan dan intonasi dalam membaca belum tepat. Faktor penyebab lain rendahnya kemampuan membaca siswa diantaranya minat baca siswa masih sangat kurang. Hal ini dibuktikan oleh masih banyaknya siswa yang malas membaca baik disekolah maupun dirumah. Bimbingan dari keluarga dan motivasi yang diberikan kepada siswa baik dari guru maupun keluarga masih kurang, serta teknik pembelajaran yang digunakan guru masih secara konvensial.

Oleh karena itu, penelitian ini diharapkan bisa memecahkan masalah yang terjadi, guna untuk meningkatkan kemampuan membaca permulaan siswa kelas I SD Negri 009 Pulau Jambu. Dari uraian permasalahan diatas, maka diperlukan suatu metode yang dapat memperbaiki permasalahan tersebut. Salah satu metode yang dapat digunakan guru sebagai cara dalam memecahkan permasalahan tersebut adalah menggunakan metode Struktural Analitik Sintetik ( SAS ).

Penggunaan metode SAS dalam pembelajaran membaca dan menulis permulaan di kelas awal, merupakan salah satu alternatif dalam membantu atau membimbing siswa ke arah penemuan sendiri, yaitu dengan menggunakan bantuan alat peraga/ media. Pembelajaran bahasa sejak dini memang tidak dapat diabaikan begitu saja, yaitu seharusnya dimulai pada usia atau kelas awal sekolah dasar. Pembelajaran ini merupakan sarana yang strategis sebagai awal dalam memperoleh pengetahuan tentang kata, dan kalimat selanjutnya dapat berkembang terus sejalan dengan pertumbuhan dan perkembangan daya nalar siswa.

Metode Struktural Analitik dan Sintetik (SAS) merupakan salah satu jenis metode yang bisa digunakan untuk proses pembelajaran membaca menulis permulaan bagi siswa pemula. Menurut (Solchan, 2014:22) menyatakan bahwa pembelajaran membaca dan menulis permulaan dengan meetode ini mengawali pelajarannya dengan menampilkan dan memperkenalkan sebuah kalimat utuh. Metode Struktural Analitik dan Sintetik (SAS) merupakan 
Jurnal Edumaspul, 5 (2), Year 2021 - 169

(Maimana, M. Syahrul Rizal, Nurhaswinda)

metode yang dikhususkan untuk belajar membaca dan menuli permulaan di kelas rendah, meskipun demikian, metode struktural analitik dan sintetik (SAS) dapat dipergunakan dalam berbagai bidang pengajaran khususnya bahasa indonesia.

Metode SAS adalah pembelajaran membaca permulaan menggunakan proses penguraian kalimat menjadi kata, kata menjadi suku kata, suku kata menjadi huruf/fonem itu kemudian dilanjutkan dengan proses sintetik. Hasil penguraian tadi dikembalikan mengikuti urutan sebagai berikut : dari huruf/fonem yang berupa suku kata, gabungan suku kata menjadi kata, dan gabungan kata menjadi kalimat semula. Metode SAS adalah salah satu metode yang memiliki 3 proses penting dengan menghubungkan huruf menjadi kata kemudian kata tersebut diuraikan dan menggabungkan kembali huruf pada struktur semula.

Lamb dan Arnold (Rahim, 2011) 2011:16) mengemukakan faktor penghambat membaca permulaan berasal dari fisiologis, intekektual, lingkungan dan psikologis. Masa anak-anak merupakan masa peka untuk menerima berbagai macam rangsangan dari lingkungan dengan menunjukkan kepekaan-kepekaan suatu masa perkembangan dimana anak usia dini memperoleh informasi-informasi baru melalui pengalamannya. Informasi tersebut diperoleh dengan melihat, mendengar dan mencoba hal-hal baru. Dari berbagai hal-hal tersebut akan berdampak positif terhadap pertumbuhan dan perkembangan. Seperti perkembangan fungsi verbal dan motorik halusnya dan keterampilan yang menyatu antar otot halus dan panca indra, seperti pertumbuhan kosa kata dan mulai tersusunnya kalimat-kalimat yang diperlukan untuk persiapan menulis dan membaca.

Perwujudan pendidikan bermutu memiliki relevansi dengan kebutuhan dan karakteristik peserta didik yang mampu bersaing dalam perkembangan ilmu pengetahuan dan teknologi di era globalisasi, serta mampu menciptakan masyarakat yang memiliki kemampuan membaca. Membaca merupakan bagian terpenting dalam perkembangan akademik seorang anak pada usia sekolah. Menurut Far dalam H. Dalman mengungkapkan "reading is the hear of education" artinya membaca merupakan jantung pendidikan. Fase perkembangan anak-anak tengah dan akhir anak sekolah dasar berlangsung pada usia (6 sampai 11 tahun), mereka mulai harus menguasai keterampilanketerampilan dasar membaca, menulis dan berhitung, memasuki dunia yang lebih luas dengan budayanya dan mulai memperhatikan pencapaian prestasi serta pengendalian diri khususnya dalam hal membaca.

Penelitian lain yang relevan pernah dilakukan sebelumnya oleh peneliti Ernalis yang hasil penelitian menunjukkan bahwa : (1) guru telah menguasai keterampilan merancang pembelajaran membaca dan menulis permulaan di sekolah dasar dengan menggunakan metode SAS ; 2) komponenkomponen pembelajaran seperti aspek: materi, strategi, metode, media, sumber belajar serta evaluasi yang dikembangkan guru telah merujuk pada tuntutan metode SAS; 3) metode SAS dalam pembelajaran membaca dan menulis permulaan, dapat diimplementasikan guru dengan siswa kelas satu sekolah dasar yang ditunjukkan peran aktif siswa kelas satu sekolah dasar; 4) penerapan metode SAS mampu meningkatkan aktivitas guru dan kreativitas siswa dalam proses pembelajaran.

Berdasarkan latar belakang di atas peneliti tertarik melakukan penelitian dengan judul "Penerapan Metode SAS Untuk Meningkatkan Kemampuan Membaca Permulaan Siswa Kelas I Sekolah Dasar 009 Pulau Jambu".

\section{Metode}

Metode yang digunakan dalam penelitian ini adalah penelitian tindakan kelas. Penelitian tindakan kelas adalah penelitian yang menggunakan seluruh siswa sebagai subjeknya ek yang dilakukan oleh guru di dalam kelas dengan tujuan untuk memperbaiki atau meningkatkan proses 
Jurnal Edumaspul, 5 (2), Year 2021 - 170

(Maimana, M. Syahrul Rizal, Nurhaswinda)

pembelajaraan (Marta, 2017: 76). Penelitian ini dilakukan di Sekolah Dasar Negeri 009 Pulau Jambu Kecamatan Kuok pada Kelas I dengan jumlah 20 siswa. Penelitian ini dilaksanakan pada semester I tahun ajaran 2020/2021. Dalam penelitian ini yang menjadi subjek penelitian adalah siswa dan guru kelas I Sekolah Dasar Negeri 009 Pulau Jambu. Dengan mata pelajaran yang diambil dalam penelitian ini adalah mata pelajaran Bahasa Indonesia.

Instrumen penelitian yang digunakan dalam penelitian ini terbagi menjadi dua kategori yakni instrumen perangkat pembelajaran berupa silabus dan RPP, dan instrumen pengumpulan data berupa lembar observasi dan tes kemampuan membaca permulaan.

Prosedur pelaksanaan penelitian tindakan kelas ini melalui 4 tahapan pada setiap siklus. Setiap siklus berisi empat langkah yaitu: tahap perencanaan, tahap pelaksanaan, tahap observasi dan tahap refleksi. Secara rinci tahapan penelitian ini dapat dijabarkan dalam gambar 1 berikut ini:

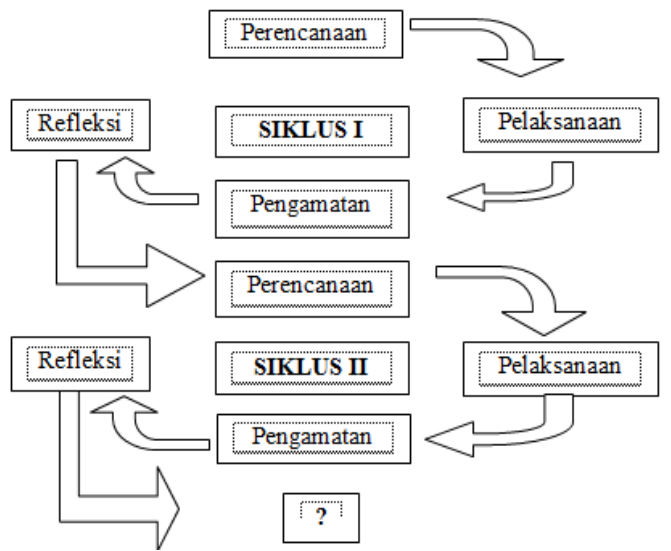

Gambar 1. Siklus Penelitian Tindakan Kelas (Arikunto, 2017:42)

Adapun prosedur penelitian dimulai dari persiapan instrumen penelitian berupa RPP, Silabus, pembuatan lembar observasi, pembuatan media pembelajaran, tahap pelaksanaan berupa pelaksanaan proses pembelajaran sesuai dengan RPP yang telah dibuat, tahap observasi berupa memonitoring kegiatan siswa, tahap refleksi berupa membahas hasil dan mengevaluasi hasil pembelajaran.

Teknik pengumpulan data dalam penelitian ini berupa observasi (berasal dari hasil lembar observasi), tes (dengan memberikan beberapa kalimat sederhana kepada siswa sesuai dengan materi pelajaran untuk mengukur hasil kemampuan membaca permulaan siswa yang diberikan dalam bentuk lisan di kelas). Dan dokumentasi (yang berasal dari pengambilan gambar oleh peneliti untuk memperkuat hasil penelitian).

Teknik analisis data yang digunakan dalam penelitian ini adalah data kualitatif dan data kuantitatif. Teknik analisis data kualitatif berupa deskripsi mengenai segala hal yang ditemui peneliti selama proses penelitian. Teknik analisis data kuantitatif diperoleh berdasarkan tes yang diberikan kepada siswa. Analisis data kuantitatif dilakukan dengan melihat ketuntasan belajar setelah menjawab soal tes yang diberikan. Tes yang dilakukan berbentuk tes lisan adalah ketuntasan klasikal tersebut denoan menogunakan rumus.

$$
K K=\frac{\text { jumlah siswa yang tuntas }}{\text { jumlah seluruh siswa }} \times 100
$$

J1ka ketuntasan klasikal siswa mencapai $75 \%$ dari seluruh siswa, maka kemampuan membaca permulaan siswa secara klasikal meningkat. Adapun kriteria kemampuan membaca permulaan dapat dilihat dari tabel berikut :

Tabel 1. Kategori Membaca Permulaan

\begin{tabular}{|c|c|}
\hline Interval (\%) & Kategori \\
\hline $85-100$ & Sangat baik \\
\hline $71-84$ & Baik \\
\hline $65-70$ & Cukup \\
\hline Kurang dari 65 & Kurang \\
\hline
\end{tabular}

\section{Hasil dan Pembahasan}

\section{Hasil Penelitian}

Hasil penelitian pada siklus I dapat jelas terlihat pada tabel 3 berikut ini :

Tabel 2. Hasil Penelitian Siklus I 
Jurnal Edumaspul, 5 (2), Year 2021 - 171

(Maimana, M. Syahrul Rizal, Nurhaswinda)

\begin{tabular}{|c|c|c|}
\hline \multirow[t]{2}{*}{ Interval } & \multicolumn{2}{|c|}{ Siklus } \\
\hline & $\mathrm{N}$ & $\%$ \\
\hline $85-100$ (Sangat Baik) & 7 & $35 \%$ \\
\hline $71-84$ (Baik) & 5 & $25 \%$ \\
\hline $65-70$ (Cukup) & 2 & $10 \%$ \\
\hline Kurang dari 65 (Kurang) & 6 & $30 \%$ \\
\hline Jumlah Siswa & 20 & $100 \%$ \\
\hline Rata-Rata & \multicolumn{2}{|c|}{76,5} \\
\hline Kategori & \multicolumn{2}{|c|}{ BAIK } \\
\hline Jumlah Yang Tuntas & 14 & $70 \%$ \\
\hline Jumlah Yang Tidak Tuntas & 6 & $30 \%$ \\
\hline
\end{tabular}

ketuntasan siswa pada siklus I mencapai $70 \%$ atau 14 siswa yang tuntas. Persentase siswa yang tidak tuntas adalah $30 \%$ atau 6 siswa. Rata-rata hasil belajar pada siklus I mencapai 76,5 dengan kategori baik. Berdasarkan hasil yang diperoleh siswa pada siklus I, dapat disimpulkan bahwa keberhasilan kemampuan membaca permulaan siswa kelas I SDN 009 Pulau Jambu telah melebihi kriteria ketuntasan minimal (KKM) adalah 70. Walaupun sudah melebihi KKM untuk lebih jelasnya penelitian ini dilanjutkan dengan siklus II.

Tabel. 3 Hasil Penelitian Siklus II

\begin{tabular}{|l|c|c|}
\hline \multirow{2}{*}{\multicolumn{1}{|c|}{ Interval }} & \multicolumn{2}{c|}{ Siklus } \\
\cline { 2 - 3 } & $\mathbf{N}$ & $\mathbf{\%}$ \\
\hline $85-100$ (Sangat Baik) & $\mathbf{1 5}$ & $\mathbf{7 5} \%$ \\
\hline $71-84$ (Baik) & $\mathbf{2}$ & $\mathbf{1 0} \%$ \\
\hline $65-70$ (Cukup) & $\mathbf{0}$ & $\%$ \\
\hline Kurang dari 65 (Kurang) & $\mathbf{3}$ & $\mathbf{1 5 \%}$ \\
\hline Jumlah Siswa & $\mathbf{2 0}$ & $\mathbf{1 0 0} \%$ \\
\hline Rata-Rata & \multicolumn{2}{|c|}{$\mathbf{8 4}$} \\
\hline Kategori & \multicolumn{2}{|c|}{ BAIK } \\
\hline Jumlah Yang Tuntas & $\mathbf{1 7}$ & $\mathbf{8 5} \%$ \\
\hline Jumlah Yang Tidak Tuntas & $\mathbf{3}$ & $\mathbf{1 5 \%}$ \\
\hline
\end{tabular}

Berdasarkan table 3, secara keseluruhan diketahui bahwa presentase ketuntasan siswa pada siklus II mencapai $85 \%$ atau 17 siswa yang tuntas. Persentase siswa yang tidak tuntas adalah $15 \%$ atau 3 siswa. Rata-rata hasil belajar pada siklus II mencapai $84 \%$ dengan kategori baik. Berdasarkan hasil yang diperoleh siswa pada siklus II, dapat disimpulkan bahwa keberhasilan kemampuan membaca permulaan siswa kelas I SDN 009 Pulau Jambu telah melebihi kriteria ketuntasan minimal (KKM) adalah 70.

\section{Pembahasan}

Penelitian tindakan kelas ini dilakukan di SDN 009 Pulau Jambu, penelitian ini dilakukan untuk mengetahui sejauh mana kemampuan membaca permulaan siswa. Kegiatan dilakukan dalam dua siklus, masing-masing siklus terdiri dari dua kali pertemuan. Sebagaimana diketahui bahwa pada siklus I hasil membaca permulaan siswa telah menunjukkan peningkatan dari sebelum tindakan, siswa yang tuntas hanya 3 siswa hal ini disebabkan guru belum menggunakan metode yang sesuai dengan kompetensi yang akan dicapai.

Untuk mengatasi kelemahan yang terjadi pada pratindakan, maka perlu dilakukan metode pembelajaran yang dapat meningkatkan membaca permulaan siswa. Salah satu metode yang dapat digunakan adalah metode struktural analitik sintetik (SAS) yang dapat membuat siswa lebih aktif dan tertarik pada pembelajaran dengan menggunakan media gambar dan melibatkan siswa dalam pembelajaran. Peneliti juga melakukan pembanding dengan penelitian lainnya yang sama-sama menggunakan metode struktural analitik sintetik (SAS) dan proses peningkatan kemampuan membaca permulaan samasama menggunakan siklus dan pada setiap siklus mengalami peningkatan, pada siklus I 76\% dan pada siklus II meningkat menjadi 84\%. Dari hasil ini menunjukkan bahwa penggunaan metode struktural analitik sintetik (SAS) dikatakan berhasil. Dengan demikian terdapat peningkatan kemampuan membaca permulaan pada siswa SDN 009 Pulau Jambu dengan menggunakan metode struktural analitik sintetik (SAS).

\section{Simpulan}

Berdasarkan hasil analisis dan pembahasan seperti disampaikan pada bab IV dapat disimpulkan bahwa penerapan metode struktural analitik sintetik (SAS) dapat meningkatkan kemampuan membaca permulaan siswa SDN 009 Pulau Jambu. Hal ini disebabkan adanya peningkatan baik 
Jurnal Edumaspul, 5 (2), Year 2021 - 172

(Maimana, M. Syahrul Rizal, Nurhaswinda)

aktivitas guru maupun aktifitas siswa dan seiring meningkatnya kemampuan membaca permulaan siswa dengan menggunakan metode struktural analitik sintetik (SAS).pada siklus I yang tuntas 12 siswa atau $60 \%$, berdasarkan dari 12 yang tuntas dikategorikan 7 siswa yang sangat baik, 5 siswa baik. Pada siklus II yang tuntas 17 siswa atau 85\%. Berdasarkan 17 siswa yang tuntas dapat dikategorikan dari 15 siswa sangat baik, 2 siswa baik dalam membaca.

\section{Daftar Pustaka}

[1] Arikunto, S. (2017). Prosedur Penelitian Suatu Pendekatan Praktik. Rineka Cipta.

[2] Marta, R. (2017). Peningkatan Hasil Belajar Matematika Dengan Model Kooperatif Tipe Think Pair Share Di Sekolah Dasar. Jurnal Cendekia:
Jurnal Pendidikan Matematika, 1(2), 74-79.

[3] Rahim, F. (2011). Pengajaran Membaca di Sekolah Dasar. Bumi Aksara.

[4] Solchan. (2014). Pendidikan Bahasa Indonesia di SD. Universitas Terbuka.

\section{Profil Penulis}

Maimana, lahir di Pulau Jambu, Kecamatan Kuok pada tanggal 31 Mei 1997, anak kelima dari lima bersaudara, pasangan Ya'kub dan Ruwaida. Penulis mulai menempuh pendidikan sekolah dasar (2005-2011), Sekolah Menengah Pertama (2011-2014), sekolah Menengah Atas (2014-2017). Pada tahun 2017 kuliah di Universitas Pahlawan jurusan S1 PGSD sampai tahun 2021. 